\title{
docosahexaenoic and eicosapentaenoic acid results in increased uptake of cadmium and elevated docosapentaenoic acid content in Hepatocytes in vitro
}

\author{
Pavla Linhartova* and Sabine Sampels
}

\begin{abstract}
Background: Human hepatocellular cells Hep G2 were used to mimic and investigate the effect of the intake of cadmium $\left(\mathrm{Cd}^{2+}\right)$ contaminated fish on cytotoxicity, fatty acid (FA) and phospholipid class composition.

Methods: Cells were incubated with a combination of $\mathrm{Cd}^{2+}$ and eicosapentaenoic acid (EPA) and docosahexaenoic acid (DHA) fish specific FA.

Results: We measured a significant increased proportion of EPA and DHA in the treated cells compared to the control line confirming the uptake. While doses of $25 \mu \mathrm{M}$ DHA showed to be toxic to the cells, repeated short term incubations $(2 \mathrm{~h})$ at lower doses resulted in an increased uptake of DHA. The resarzurin assay, evaluating cell viability, showed a significant decrease in cell viability between $\mathrm{Cd}^{2+}$ incubation time and, further, the pre-incubation with BSA-FA complex resulted in significantly increased cell viability. On the metabolic level, increased concentrations of EPA and DHA resulted in an increased proportion of docosapentaenoic acid (DPA) which indicated an increased metabolism. Also 24-h

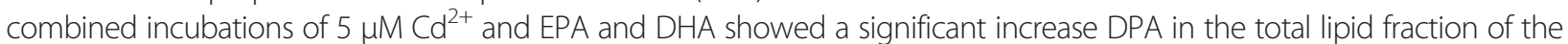
cells. In addition, incubation with $5 \mu \mathrm{M} \mathrm{Cd}{ }^{2+}$ for $24 \mathrm{~h}$ also decreased the total cardiolipin (CL) fraction from the identified phospholipids.
\end{abstract}

Conclusions: We confirmed that the applied FA were taken up by the cells. A combination of EPA, DHA and $\mathrm{Cd}^{2+}$ influenced lysosomal integrity, cell viability and lipid metabolism in the cells. The most important finding is that DHA and EPA reduced the detrimental effect of $\mathrm{Cd}^{2+}$ on cell viability. The exact effects and kinetics behind our observations still need further evaluation.

Keywords: DHA, EPA, Fish lipids, Hep G2, Omega-3 fatty acids

\section{Background}

Balancing risks and benefits of fish consumption is an intensively discussed public health topic [1-3]. The health benefits from eating fish, partly attributable to omega-3 polyunsaturated fatty acids ( $n-3$ PUFA), are well documented both for prenatal development and

\footnotetext{
* Correspondence: linhap01@frov.jcu.cz

Faculty of Fisheries and Protection of Waters, South Bohemian Research Center of Aquaculture and Biodiversity of Hydrocenoses, Institute of Aquaculture and Protection of Waters, University of South Bohemia in Ceske Budejovice, Husova Tř. 458/102, 37005 České Budějovice, Czech Republic
}

adult cardiovascular conditions $[4,5]$. Due to their lipophilicity, fish take up and bioaccumulate heavy metals via feed and from the water, which in turn passes up the food chain into the human diet [6]. There have been no studies on the combined effects of FA and $\mathrm{Cd}^{2+}$ on cell cytotoxicity.

$\mathrm{Cd}^{2+}$ is an environmental pollutant which is taken up with drinking water and food, including seafood and fish. The TDI (daily tolerable intake) for $\mathrm{Cd}^{2+}$ was calculated according to the guidelines suggested by the Institute of Standard and Industrial Research of Iran (ISIRI). Based on ISIRI, the tolerable daily intake for $\mathrm{Cd}^{2+}$ is $1 \mu \mathrm{g} /$ day $\mathrm{kg}$ of 
bw (body weight), [7]. Inorganic $\mathrm{Cd}^{2+}$ is a human carcinogen [8] and is classified as cancerogenic compound by the International Agency for Research on Cancer (IARC) [9]. Long-term exposure to low concentrations of $\mathrm{Cd}^{2+}$ result in accumulation in the liver and the kidneys (kidney cortex) where $30-60 \%$ of ingested $\mathrm{Cd}^{2+}$ is deposited [10]. $\mathrm{Cd}^{2+}$ compounds have toxic effects on the kidney and are assumed to be neurotoxic. These effects could be due to oxidative stress, but also by different mechanisms that affect the cell membrane composition $[11,12] . \mathrm{Cd}^{2+}$ acts as a catalyst during the formation of reactive oxygen species (ROS).

The long chain n-3 PUFA EPA and DHA have many metabolic functions in animals and humans. Mammals lack the $\Delta 15$ desaturase that is essential for insertion of double bonds at $\mathrm{n}-3$ and hence cannot synthesize the parent FA 18:3 n-3 [13]. In addition it has not been established whether mammals are able to elongate and desaturate 18:3n-3 towards 20:5 n-3, 22:5 n-3 and 22:6 $\mathrm{n}-3$ in significant amounts [14-16]. Therefore, these FA are regarded as essential for humans and they need to be included in the diet. They are vital nutrients and precursors of several metabolites, which are potent lipid mediators, known to be beneficial in the prevention and treatment of several diseases [17]. Fish are an important source of these FA and hence the consumption of fish (200 g portion) at least twice a week is recommended by several health organizations including FAO/WHO [18]. In the same report, the negative effects of eating contaminated fish are out weight against the benefits of the FA. However, it is unclear which exact mechanisms are affected by cadmium intake in relation to lipid metabolism and oxidative stress when it is simultaneously taken up with the long chain n-3 FA from fish.

The aim of the present study was therefore to evaluate the combined effects of the nutritional essential FA EPA and DHA from fish and $\mathrm{Cd}^{2+}$. Our hypothesis took two aspects into account: $\mathrm{Cd}^{2+}$ is known to create oxidative stress in the cells, so one of the toxic effects could be the oxidation of important membrane or organelle FA or phospholipids, subsequently leading to cellular dysfunction or apoptosis. If contaminated fish are ingested, the long chain n-3 FA from the fish, which are the FA most easily oxidized, could prevent or decrease the impact of $\mathrm{Cd}^{2+}$ either by replacing the oxidized FA, or conversely by increasing the oxidative stress and thereby worsen the effects of the $\mathrm{Cd}^{2+}$. Hepatocytes were selected for the investigation because the liver is a target organ for $\mathrm{Cd}^{2+}$. A combination of DHA/EPA as $2 / 1$ reflects the typical ratio in many fatty fish, common carp (Cyprinus carpio) for example, which is traditionally consumed in Czech Republic. In order to mimic the uptake of contaminated fish, we investigated the metabolic effects of cadmium $\left(\mathrm{Cd}^{2+}\right)$ on the cell line Hep $\mathrm{G} 2$ in combination with the long chain n-3 PUFA, eicosapentaenoic acid (EPA; 20:5 n-3) and docosahexaenoic acid (DHA; 22:6 n-3) which are typical for fish $[19,20]$.

\section{Methods \\ Caution}

Inorganic cadmium chloride $\left(\mathrm{CdCl}_{2}, \mathrm{Cd}^{2+}\right)$ is classified as a human carcinogen [21] it is hazardous, or potentially hazardous and should be handled with care.

\section{Chemicals}

Eicosapentaenoic acid (EPA) and docosahexaenoic acid (DHA) supplied from Biochrom and Sigma-Aldrich (Berlin, Germany), were diluted in extra pure $98 \%$ ethanol and bovine serum albumin (BSA) before transfer experiments. Hydrogen peroxide solution (30\%, Suprapurs) and nitric acid (65\%, Suprapur) were products of Merck (Darmstadt, Germany). Cadmium chloride was obtained from Aldrich, Germany. All other pro-analysis chemicals were obtained from Sigma-Aldrich (Steinheim, Germany) and Merck (Darmstadt, Germany). Trypsin, penicillin and streptomycin solutions were products of Sigma (Deisenhofen, Germany). Moreover, the culture dishes and the culture medium (MEM) for Hep G2 cells were obtained from Biochrom (Berlin, Germany).

\section{Cell culture}

Human hepatocellular cells (Hep G2, ATCC, No. HB-8065) were purchased from the American Type Culture Collection (ATCC, Manassas, V C, USA). Hep G2 cells were grown as a monolayer in culture dishes in Minimum Essential Medium Eagle (MEM) supplemented with FCS $(10 \%, v / v)$, non-essential amino acids $(1 \%, \mathrm{v} / \mathrm{v})$, glutamine $(2 \mathrm{mM})$, penicillin $(100 \mathrm{U} / \mathrm{mL})$ and streptomycin $(100 \mu \mathrm{g} / \mathrm{mL})$. The Hep G2 cultures were incubated at $37{ }^{\circ} \mathrm{C}$ with $5 \% \mathrm{CO}_{2}$ in air with $100 \%$ humidity. Cells were passaged every 3 days. The amount of 1.5 million cells were seeded on $10 \mathrm{~cm}$ (in diameter) sterile Petri dishes in $10 \mathrm{~mL}$ of sterile culture medium (MEM). Suspensions of Hep G2 cells were produced from confluent cultures using trypsin/EDTA solution. Before the transfer experiments, cells were three times sub-cultured to achieve a stable phenotype. For the transfer experiments, cells were seeded at a density of 66.7 cells per $\mu \mathrm{L}$ for 96 well plates and 1.5 Mio (million) per normal petri dishes (10 cm in diameter). Seeded Hep G2 were cultured for $24 \mathrm{~h}$ and $37{ }^{\circ} \mathrm{C}$ and subsequently prepared for preincubations and post-incubations with FA and $\mathrm{Cd}^{2+}$. Hep G2 cells where used from passage Nr. 20 at least 3-4 weeks (till passage Nr. 35). Hep G2 cells can be used from the third passage to Nr. 130. Hep G2 cells were incubated with $\mathrm{Cd}^{2+}$ only, with $\mathrm{Cd}^{2+}$ and with BSA solved in PBS in order to evaluate if the BSA alone would have any effects 
and finally with $\mathrm{Cd}^{2+}$ and the FA (EPA + DHA) as a BSAFA complex.

\section{EPA and DHA pre-incubations}

Before incubation fresh stock solutions of FA diluted in extra pure $98 \%$ EtOH were defrosted. The BSA-FA complex was prepared as follows: BSA was dissolved in PBS (phosphate buffer saline). EPA and DHA were dissolved in extra pure $\mathrm{EtOH}$ to a final volume of $50 \mu \mathrm{L}$. Then $20 \mu \mathrm{L}$ of EPA and DHA solutions were added to $1 \mathrm{ml}$ of a mixture of $0.1 \mathrm{M} \mathrm{NaOH}$ and BSA solution $(1 / 5 ; \mathrm{v} / \mathrm{v})$ each. The two solutions of FA were then combined and the $\mathrm{pH}$ was adjusted to 7.1 using $0.1 \mathrm{M} \mathrm{HCl}$. After testing concentrations from 1-50 $\mu \mathrm{M}$ EPA and from 2-100 $\mu \mathrm{M}$ DHA, we chose concentrations for pre-incubations of liver human cells with $5 \mu \mathrm{M}$ EPA $+10 \mu \mathrm{M}$ DHA for $2-48 \mathrm{~h}$ without changing the cell culture medium (MEM).

\section{$\mathrm{Cd}^{2+}$ post-incubations}

Fresh stock solutions of $\mathrm{Cd}^{2+}$ diluted in distilled sterile water $\left(\mathrm{ddH}_{2} \mathrm{O}\right)$ were prepared before the transfer experiments. Hep G2 liver cells were post-incubated for $24 \mathrm{~h}$ or $48 \mathrm{~h}$ with $\mathrm{Cd}^{2+}$ stock solution with changing the cell culture medium (MEM). The range of $\mathrm{Cd}^{2+}$ concentrations were used from min. $0.25 \mu \mathrm{M}$ to max. $20 \mu \mathrm{M}$.

\section{Cytotoxicity and lysosomal integrity}

The neutral red assay was used to assess the impact of the heavy metal on lysosomal integrity [22] using a plate reader (Invinite 200Pro, Tecan Group Ltd., Mannedorf, Switzerland). The levels of $\mathrm{IC}_{50}$ and $\mathrm{IC}_{70}$ were measured so as to indicate the percentage of control in the parameter of lysosomal integrity.

\section{Cytotoxicity and cellular viability}

Cellular viability, was measured with the resarzurin uptake assay [23] using a plate reader (Invinite 200Pro, Tecan Group Ltd., Mannedorf, Switzerland). The levels of $\mathrm{IC}_{50}$ and $\mathrm{IC}_{70}$ were measured so as to indicate percentage of control in the parameter of cell viability.

\section{Pelleting of Hep G2 cells}

Cells were seeded in number of 1.5 million cells per Petri dish to $10 \mathrm{~mL}$ MEM sterile culture medium. Seeded Hep G2 were cultured and treated with FA as a BSA-FA complex and $\mathrm{Cd}^{2+}$ for the appropriate times as described above. Subsequently cells were pelleted by trypsinising and centrifuging several times in PBS/FKS solution and frozen on $-80{ }^{\circ} \mathrm{C}$.

\section{Fatty acid composition and phospholipid classes}

The pelleted cells were re-suspended in buffer and the total lipids were extracted from cells according to Hara and Radin [24]. From these extracts, the composition of major lipid classes as well as phospholipid classes were evaluated via automated high performance thin layer chromatography (HPTLC), [24, 25]. For analyses of FA composition, methylation of total lipids was performed by using a combination of $\mathrm{NaOH}$ and $\mathrm{BF}_{3}$ according to Appelqvist [26]. FA composition was then analyzed by GC on a BPX-70 $50 \mathrm{~m}$ fused silica capillary column (id. $0.22 \mathrm{~mm}, 0.25 \mu \mathrm{m}$ film thickness, SGE, USA) as described Sampels et al. [27]. Identification of FA and phospholipid classes was done by commercially available external standards (Nu-Check Prep, Inc. Elysian USA; Avanti Polar Lipids, Inc., Alabama, USA) quantification of the FA was done by internal standard (C 21:0, NuCheck Prep, Inc. Elysian USA). Total fat and phospholipids and FA as \% of total identified per million cells in $\mu \mathrm{g}$ were evaluated.

\section{Determination of cadmium uptake}

The content of cadmium chloride was analyzed via ICP-MS as described earlier [28]. Quantification was performed with authentic standards. $\mathrm{Cd}^{2+}$ concentration in $\mu \mathrm{M}$ in pelleted cells was analyzed.

\section{Statistical analysis}

All analyses were conducted in triplicate or quadruplicate. Normality and homogeneity of dispersions of studied values and comparisons were made by analysis of variance (two factorial ANOVA; factors: $\mathrm{Cd}^{2+}$ and FA) with subsequent post hoc Tukey's honest significant difference (HSD) test. The values were expressed as means $\pm \mathrm{SD}(n=3)$. All analyses were performed at a significance level of $p<0.05$ using STATISTICA 9.0 for Windows.

\section{Results}

\section{FA concentrations suitable for incubation trials}

In order to establish suitable incubation concentrations of FA, we first incubated the cells with the individual FA ranging for EPA from $1 \mu \mathrm{M}$ to $50 \mu \mathrm{M}$ (Fig. 1a) and for DHA from $2 \mu \mathrm{M}$ to $100 \mu \mathrm{M}$ (Fig. 1b), respectively. For $\mathrm{EPA}$, the highest $50 \mu \mathrm{M}$ concentration was above toxic effects for the cells (Fig. 1a). Neither the level of $\mathrm{IC}_{50}$, nor level of the $\mathrm{IC}_{70}$ was reached. No significant change on cell growth measured by lysosomal integrity was found for this FA. For DHA, significant changes were found only between control line (Hep G2) and cells treated with $25 \mu \mathrm{M}$ DHA and higher DHA concentrations showed significant toxic effects on the cells (Fig. 1b). A significantly negative effect of DHA on Hep G2 cell growth was observed after in vitro for $24 \mathrm{~h}$ at concentrations $50 \mu \mathrm{M}$ DHA $\left(\mathrm{IC}_{70}\right)$ and the $\mathrm{IC}_{50}$ was reached at the level of $76 \mu \mathrm{M}$ DHA (Fig. 1b). Furthermore, the cells showed only $29.3 \%$ vitality at a level of $100 \mu \mathrm{M}$ DHA (Fig 1b). In a second step we evaluated 


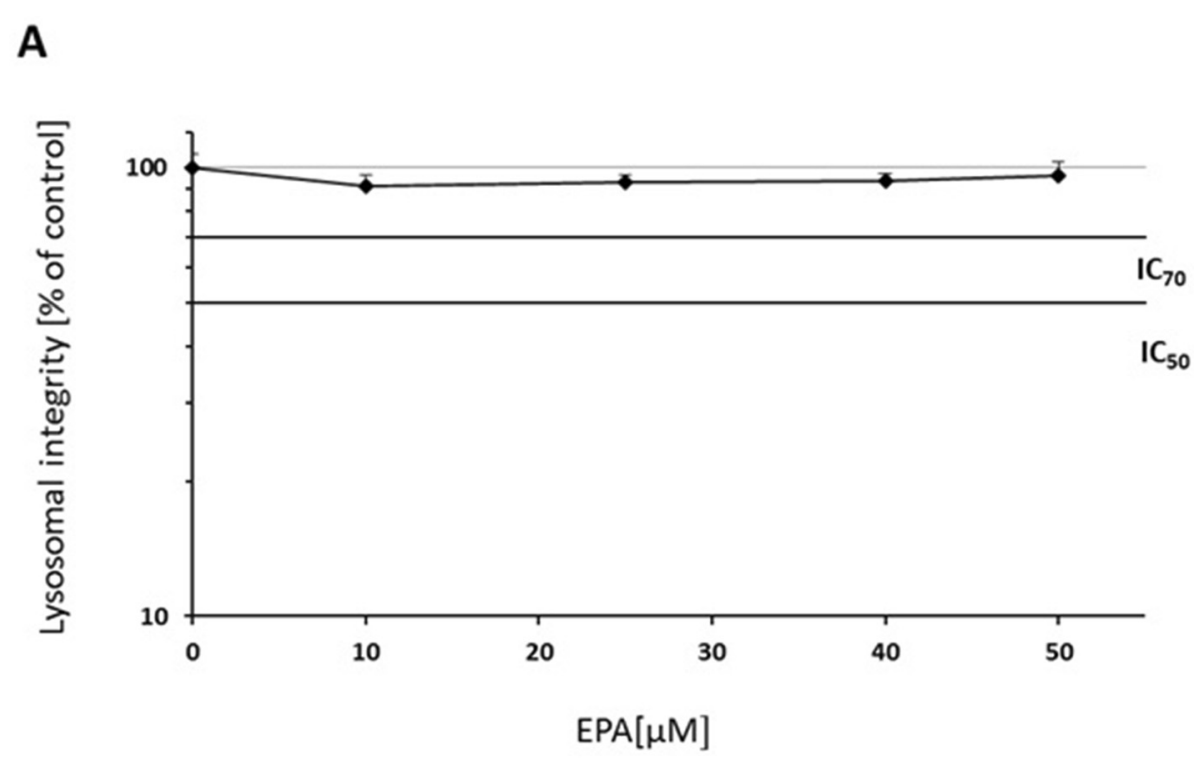

B

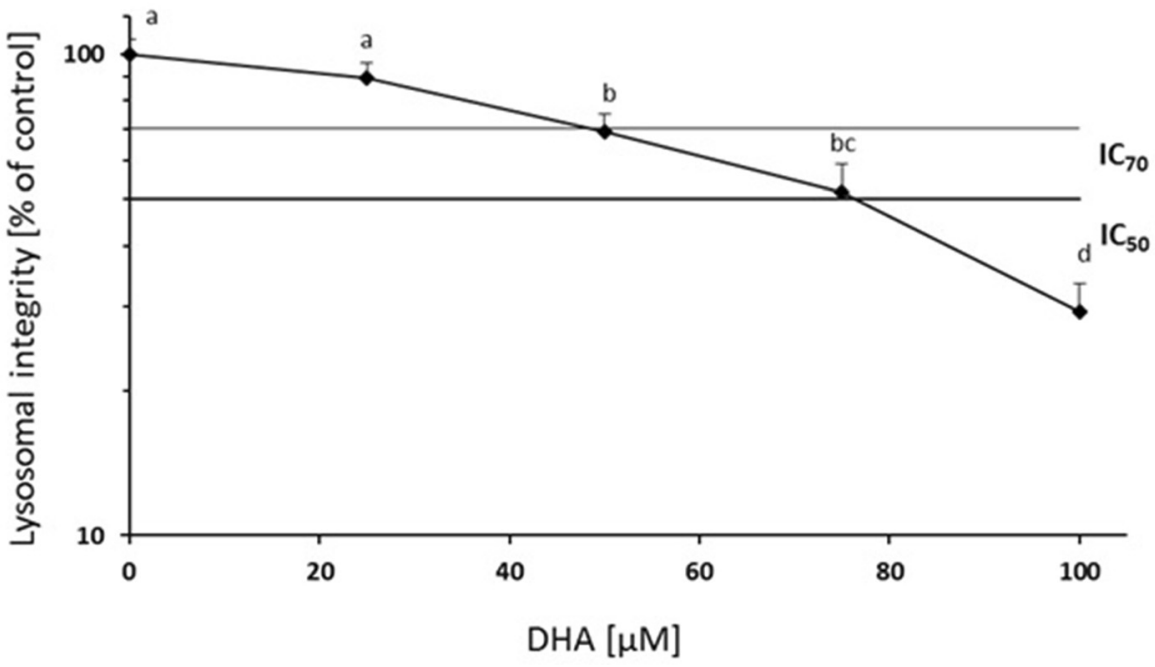

Fig. 1 Lysosomal integrity after in vitro pre-incubations of Hep G2 for $24 \mathrm{~h}$ with EPA (a) at nominal concentrations of 10, 25, 40 and 50 $\mu \mathrm{M}$ and DHA (b) at nominal concentrations of 25, 50,75 and $100 \mu \mathrm{M}$ compared to control cells. Data are presented as means $\pm S D, n=3$. Different letters denote significant difference between treatments (ANOVA, $p<0.05$ )

the effects of the incubation with a combination of EPA and DHA. The combination of $40 \mu \mathrm{M}$ EPA+ $75 \mu \mathrm{M}$ DHA resulted in a cell viability significantly below $50 \%$ (18.9\% viable cells), while the combination of $10 \mu \mathrm{M} E P A+20 \mu \mathrm{M}$ DHA, was above the level $\mathrm{IC}_{70}$ (85.3\% vital cells) (Fig. 2), but was significantly lower compared to the control cells without added FA. As the level of DHA was still too high, we decreased the concentration to a combination of $5 \mu \mathrm{M} \mathrm{EPA}+10 \mu \mathrm{M}$ DHA (Fig. 2). With these concentrations a cell viability of $96.9 \%$ (EPA5 + DHA10) was reached. No cytotoxic effects of FA on cell growth in this combination with control line were found.

\section{Cell viability}

The resarzurin assay, evaluating cell viability, showed a significant correlation between $\mathrm{Cd}^{2+}$ incubation time and decreasing cell viability; an $\mathrm{IC}_{50}$ value of $6.6 \mu \mathrm{M}$ and $\mathrm{IC}_{70}$ of $4 \mu \mathrm{M}$ were measured after $24 \mathrm{~h}$ (Fig. 3a: Hep G2) and an $\mathrm{IC}_{50}$ value of $4.1 \mu \mathrm{M}$ and $\mathrm{IC}_{70}$ of $3 \mu \mathrm{M}$ after $48 \mathrm{~h}$ (Fig. 3b: Hep G2). Cell viability was significantly different in comparison to the control cells at $5 \mu \mathrm{M} \mathrm{Cd}^{2+}$ for both incubation times (Fig. 3ab). 


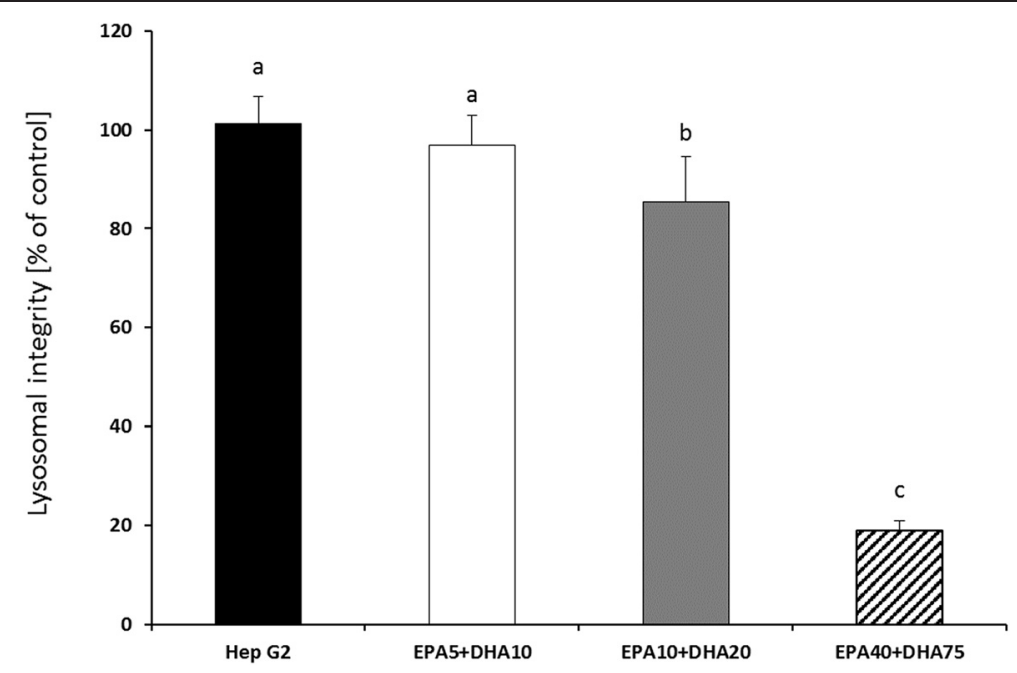

Fig. 2 Lysosomal integrity after in vitro pre-incubations of Hep G2 for $24 \mathrm{~h}$ with combined EPA+DHA. Nominal concentrations of EPA5 + DHA10 $\mu M$, $\mathrm{EPA} 10+\mathrm{DHA} 20 \mu \mathrm{M}$ and EPA40 + DHA75 $\mu \mathrm{M}$ compare to control cell line (Hep G2). Data are presented as means $\pm \mathrm{SD}, n=3$. Superscript letters indicate significant differences between treatments (ANOVA, $p<0.05$ )

Pre-incubation with the BSA-FA complex resulted in significantly increased cell viability at concentrations starting at $5.5 \mu \mathrm{M} \mathrm{Cd}{ }^{2+}\left(\mathrm{IC}_{70}\right)$ for FA group in comparison with only $4 \mu \mathrm{M} \mathrm{Cd^{2+ }}$ for control-Hep G2 $\left(\mathrm{IC}_{70}\right)$ and only $3.6 \mu \mathrm{M} \mathrm{Cd}{ }^{2+}\left(\mathrm{IC}_{70}\right.$ : Hep $\left.\mathrm{G} 2+\mathrm{BSA}\right)$, after $24 \mathrm{~h}$ post-incubations with $\mathrm{Cd}^{2+}$ (Fig. 3a). No effects of BSA dissolved in PBS alone incubated with the cells (Hep G2 + BSA) were found compare to control (Hep G2), which demonstrated that the BSA can be used without affecting cell growth (Fig. 3ab).

\section{Hep G2 lipid composition: phospholipids and fatty acids}

Table 1 shows the contents of the long chain omega3FA (EPA, DPA, DHA) in the cells with or without incubation of the FA for $24 \mathrm{~h}$. A significant increase in the cells of both EPA and DHA was shown after the incubation (Fig. 4a and b). We demonstrated that after only two hours the maximum uptake of FA (Fig. 4b) was reached and there were no significant difference between 2, 24 or $48 \mathrm{~h}$ of FA incubation per million cells in Fig. 4a. Further we showed that repeated incubations were more effective. This was probably due to the totally increased substrate. After three replicated 2-h incubations with EPA or DHA (total $6 \mathrm{~h}$ of FA incubation of the cells with changing the medium every $2 \mathrm{~h}$ ) proportions of FA in the cells were significantly increased compared to all other treatments and without toxic effects. When expressed as percentage of total fat, the increase of DPA was also significant after the incubation with FA; this suggests a synthesis from EPA toward DHA (Fig. 4b). When expressed as $\mu \mathrm{g}$ of fat per million (Mio.) cells, the increase of DPA was significant for only the $3 \times 2$-h incubation, which supports the hypothesis that an increased proportion of EPA will lead to an increased metabolism towards DHA (Fig. 4a). The level of EPA reached $1.31 \mu \mathrm{g}$ per Mio. cells and the DHA level was almost eight times higher (2.33 $\mu \mathrm{g}$ per Mio. cells) compared to untreated cells (Fig. 4a). Moreover, EPA increased to $9.5 \%$ and DPA to $3.3 \%$ and the DHA level was almost three times higher (15.4 \% of total identified FA than the untreated cells (Fig. 4b). In the control line, without FA incubation, both EPA and DPA showed levels of $0.6 \%$ and DHA $2.7 \%$ of total identified FA (Fig. 4b). Even though uptake had reached the maximum after $2 \mathrm{~h}$, for practical reasons we decided to use 24-h pre-incubations for the subsequent FA and $\mathrm{Cd}^{2+}$ experiments.

Incubation with $\mathrm{Cd}^{2+}$ did not influence the content of EPA or DHA, (Table 1). However the subsequent incubation of the cells with the FA and $5 \mu \mathrm{M} \mathrm{Cd}^{2+}$ resulted in a significant increase of DPA.

There were no significant differences in phospholipid composition of the cells related to the pre-incubation with FA. Therefore, the data were combined to facilitate statistical evaluation. Figure 5 shows the phospholipid class composition in the Hep G2 after the various incubations. The phospholipids cardiolipin (CL) decreased significantly after incubation with $5 \mu \mathrm{M} \mathrm{Cd}^{2+}$ for $24 \mathrm{~h}$. At this level of cadmium, only $12.1 \%$ of $\mathrm{CL}$ were detected in cells compared to $14.9 \%$ at $1 \mu \mathrm{M} \mathrm{Cd}^{2+}$ and $15.4 \%$ without any cadmium treatment (Fig. 5). The decrease of CL between $1 \mu \mathrm{M}$ and $5 \mu \mathrm{M}$ incubations was significant $(p<0.05)$.

\section{Uptake of $\mathrm{Cd}$ in relationship with $\mathrm{FA}$}

Figure 6 shows the result from $\mathrm{Cd}$ uptake, which was verified by ICP-MS. Three different concentrations of 

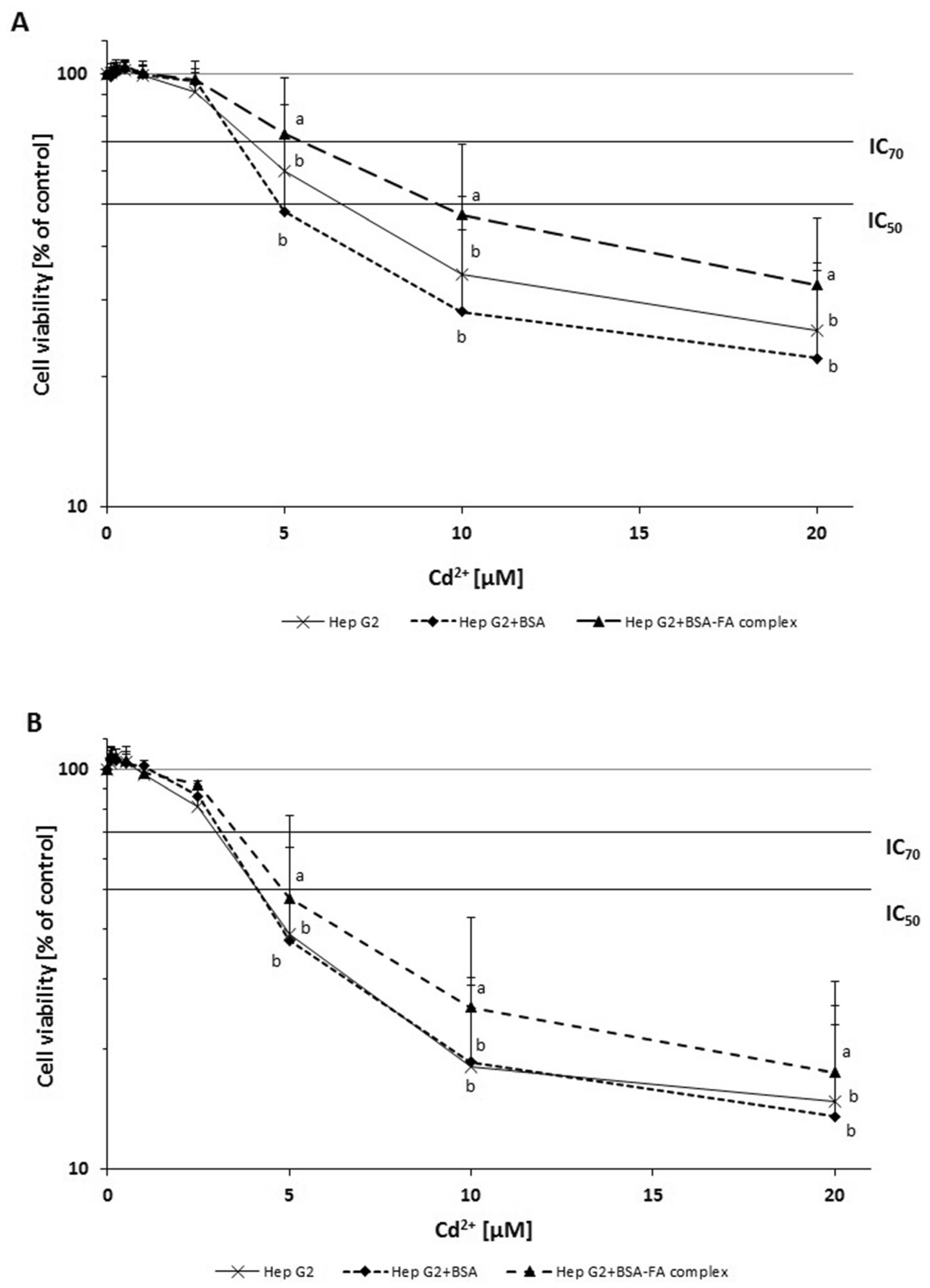

Fig. 3 Cell viability after in vitro pre-incubations of Hep G2 for $24 \mathrm{~h}$ with $5 \mu \mathrm{M}$ EPA+ $10 \mu \mathrm{M}$ DHA dissolved as BSA complex and $24 \mathrm{~h}$ (a) and $48 \mathrm{~h}$ (b) post-incubations with $\mathrm{Cd}^{2+}$ at nominal concentrations of $0.25,0.5,1,2.5,5,10,20 \mu \mathrm{M}$ with changing culture (MEM) medium. Data are presented as means $\pm S D, n=3$. Different letters denote significant differences between treatments (two factorial, $A N O V A,\left(F A, C d^{2+}\right), p<0.05$ ) 
Table 1 Fatty acid content in Hep G2 cells

\begin{tabular}{|c|c|c|c|c|}
\hline$\mu \mathrm{g}$ FA per Mio cells & BSA-control no FA & BSA-FA (24 h) & BSA-control no FA Cd5 (24 h) & BSA-FA (24 h) Cd5 (24 h) \\
\hline$C 20: 5 n-3$ & $0.09 \pm 0^{\mathrm{a}}$ & $0.37 \pm 0.09^{b}$ & $0.14 \pm 0.05^{a}$ & $0.59 \pm 0.14^{b}$ \\
\hline$C 22: 5 n-3$ & $0.10 \pm 0.01^{a}$ & $0.16 \pm 0.03^{\mathrm{ab}}$ & $0.17 \pm 0.07^{\mathrm{ab}}$ & $0.31 \pm 0.06^{b}$ \\
\hline$C 22: 6 n-3$ & $0.40 \pm 0.06^{\mathrm{a}}$ & $0.84 \pm 0.08^{b}$ & $0.57 \pm 0.22^{a}$ & $1.23 \pm 0.19^{b}$ \\
\hline SFA & $5.61 \pm 0.98$ & $5.47 \pm 0.66$ & $7.24 \pm 3.20$ & $8.38 \pm 2.19$ \\
\hline MUFA & $8.19+0.98^{\mathrm{a}}$ & $6.02 \pm 0.33^{b}$ & $8.65 \pm 2.88^{\mathrm{ab}}$ & $7.48 \pm 1.30^{b}$ \\
\hline PUFA & $2,00 \pm 0.29^{a}$ & $2.60 \pm 0.28^{b}$ & $2.84+1.08^{\mathrm{ab}}$ & $4.01 \pm 0.44^{b}$ \\
\hline$n-3$ & $0.59 \pm 0.07^{\mathrm{a}}$ & $1.38 \pm 0.10^{b}$ & $0.88 \pm 0.34^{a}$ & $2.13 \pm 0.23^{b}$ \\
\hline$n-6$ & $1.36 \pm 0.26^{\mathrm{ab}}$ & $1,20 \pm 0,19^{b}$ & $1.94 \pm 0.76^{\mathrm{a}}$ & $1.81 \pm 0.30^{\mathrm{ab}}$ \\
\hline$n-6 / n-3$ & $2.28 \pm 0.18^{\mathrm{a}}$ & $0.87 \pm 0.08^{b}$ & $2.21 \pm 0.02^{\mathrm{a}}$ & $0.85 \pm 0.08^{b}$ \\
\hline
\end{tabular}

FA content (\% of total identified) in Hep G2 cells incubated with or without FA ( $24 \mathrm{~h}$ ) and subsequently with or without $5 \mu \mathrm{M}$ Cd ${ }^{2+}$ for $24 \mathrm{~h}$. 'No FA' means cells were only incubated with BSA as control. Data are presented as means $\pm \mathrm{SD}, n=3$. Different letters denote significant differences between treatments (two factorial ANOVA, $\left.\left(\mathrm{FA}, \mathrm{Cd}^{2+}\right), p<0.05\right)$

Abbreviations: PC L a-Phosphatidylcholine, CL Cardiolipin, PA L-a-Phosphatidic acid, and EA Phosphatidylethanolamine

Cd $(1,2.5$ and $5 \mu \mathrm{M})$ were tested. One-half of pelleted cells was pre-incubated with FA for $24 \mathrm{~h}$ and all groups where then post-incubated with $\mathrm{Cd}^{2+}$ for the same time. The group incubated with the highest $5 \mu \mathrm{M} \mathrm{Cd}^{2+}$ and FA (5 $\mu \mathrm{M} \mathrm{EPA}+10 \mu \mathrm{M}$ DHA), had a significantly higher uptake of cadmium chloride (457.6 365.8 $\mu \mathrm{M})$, compared to the group not treated with FA $\left(365.8 \mu \mathrm{M} \mu \mathrm{M} \mathrm{Cd}^{2+}\right)$.

\section{Discussion}

In the present study we used a combination of EPA + DHA in a ratio 1:2 which is a proportion of FA typical for fatty fish such as common carp (Cyprinus carpio); carps are available on the local market year round [29]. Despite that fact that $60 \mu \mathrm{M}$ DHA has been considered as physiological relevant [30], we found that the $\mathrm{IC}_{70}$ level had been already reached at $50 \mu \mathrm{M}$ DHA. Our findings are in agreement with earlier results that DHA has cytotoxic effects on cancerogenic cells; similar toxic effects of DHA on cancerogenic neuroblastoma cells but not on non-transformed nervous tissue have been reported by Lindskog et al. [31]. These authors concluded that DHA counteracted cancer by causing apoptosis in the cancer cells. Juaudzus et al. [32] also showed that relatively high doses of DHA did not affect healthy cells. In the cell lines MIA PaCa-2, PANC-1 and CFPAC (human pancreatic cell lines), EPA was also shown to have an inhibitory effect of cell growth ( $\mathrm{IC}_{50}$ 2.5-5 $\mu \mathrm{M}$ ), [33]. In contrast, we found cytotoxic effects of DHA but not of EPA at concentrations of $50 \mu \mathrm{M}$. The mechanisms by which DHA acts differentially on cancerogenic versus normal healthy cells are still under discussion. In their review [34] describes the main mechanism to oxidative stress created by oxidation compounds derived from DHA. Due to their increased metabolism, cancer cells have increased natural levels of ROS and additional ROS can then not be counteracted as well as in healthy cells where the antioxidant mechanisms are still intact.
According to our results in the present setting, $5 \mu \mathrm{M}$ $\mathrm{EPA}+10 \mu \mathrm{M}$ DHA were the most suitable incubation concentrations for hepatocellular human liver cells (Hep G2; ATCC). We showed that the effect of EPA and DHA on the cells seems to be different, which should be evaluated further.

We showed that the incubated FA was taken up by the cells (Table 1), however, we found an increase of those FA only in the total lipid fraction (Table 1) and not in the subcellular lipid fractions (data not shown), indicating that an incubation time up to $48 \mathrm{~h}$ is probably too short for the FA to be incorporated into the cell structure.

When evaluating the incubation times, the maximum uptake already had been reached after only $2 \mathrm{~h}$ incubation with FA. After this, the proportion of the used FA did not significantly further. In contrast, Obermeier et al. [35] showed that the maximum levels of incorporation of AA, EPA, and DHA into U937 cell (human leukemic monocyte lymphoma cell line) was reached after $8 \mathrm{~h}$. This finding suggests that different cell types might have different time optima for the uptake. Consequently, we decided to use 24-h incubation times for improved practical handling and to ensure a good repeatability.

In line with our results, Fujiyamafujiwara et al. [36] also found that incubation of Hep G2 cells with EPA resulted in a dose-dependent incorporation of EPA and a metabolism towards DPA but not DHA. The authors also found an increase of DHA, but a lower dose dependency, plus an increased amount of DPA in the cells after incubation with DHA, suggesting that DHA was $B$-oxidized into DPA. These findings support our hypothesises that an increased proportion of substrate, in our case EPA, results in increased synthesis of the longer chain FA as well as a higher B-oxidation of increased amounts of DHA into DPA.

In addition, we showed that repeated incubations are more effective. This is probably due to the totally increased 


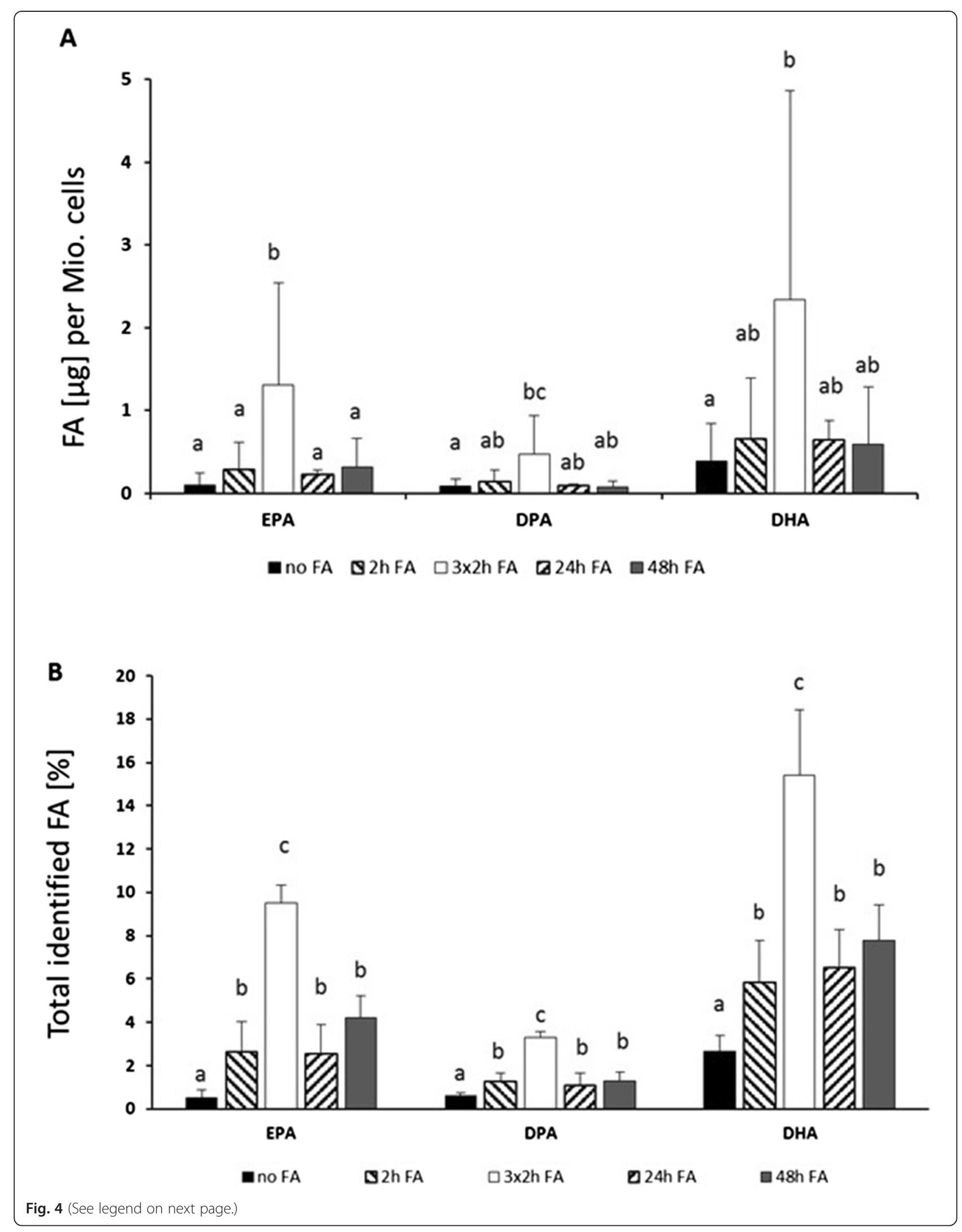


(See figure on previous page.)

Fig. 4 Content of EPA, DPAn-3, DHA and total amount of FA after in vitro incubations of Hep G2 for 2, 3×2, 24 and 48 h with $5 \mu \mathrm{M}$ EPA+ $10 \mu \mathrm{M}$ DHA as BSA complex and different subsequent time of cell growth (30,48 and 96 h), presented as $\mu \mathrm{g}$ of FA per Mio. cells (a) and total identified FA (\%) content (b). 'No FA' means cells were only incubated with BSA as control. Data are presented as means \pm SD, $n=3$. Different letters denote significant differences of the respective FA between incubation times (ANOVA, $p<0.05$ )

substrate. In this way it seems to be possible to load the cells with greater amounts of EPA and DHA without the toxic effects caused by higher concentrated doses. This finding could be useful in future studies of the effects of elevated PUFA levels. On a metabolic level, the increased substrate also seems to result in a higher metabolism from EPA towards DPA and possibly DHA.

One of our hypotheses was that $\mathrm{Cd}^{2+}$ could cause a change in the cell lipid composition resulting in dysfunction and finally apoptosis. The results from the resazurin assay, with a significant correlation between $\mathrm{Cd}^{2+}$ incubation time and decreasing cell viability concurred with this, as the resarzurin method is based on the fact that normal viable and healthy cells reduce the blue resazurin to the pink resorfin. It is known that resazurin is effectively reduced in the mitochondria, making it useful also to assess mitochondrial metabolic activity. Hence we think that $\mathrm{Cd}^{2+}$ affects the mitochondrial functions. A reason for this could be oxidation of essential membrane lipids. An indication for this is that the highest used concentration of $\mathrm{Cd}^{2+}$ resulted in also decreased levels of cardiolipin (CL) in our study. CL is exclusively localized in the inner mitochondrial membrane and important for mitochondrial membrane functionality [37]. CL is especially sensitive to oxidation due to the high content including DHA [34]. Increased oxidation and subsequent decrease of CL has been connected to apoptosis [34] which is also inferred by our study.

In conclusion, our results, showed that a decrease in the proportion of $\mathrm{CL}$ together with a decreased cell viability, indicating that $\mathrm{Cd}^{2+}$ has an effect on cellular lipid composition and mitochondrial function.

Interestingly, the co-incubation of FA and $\mathrm{Cd}^{2+}$ resulted in a significantly higher uptake of $\mathrm{Cd}^{2+}$ at the highest concentrations of $\mathrm{Cd}^{2+}(5 \mu \mathrm{M})$, while the uptake seemed to reach a maximum level at $2.5 \mu \mathrm{M}$ (Fig 6). This finding is in contrast to a study by Nostbakken et al., [38] evaluating the effect of EPA and DHA on methyl mercury (MeHg) uptake. In that study DHA decreased the uptake of $\mathrm{MeHg}$ in HEK293. In line with our results, DHA increased the uptake of the heavy metal and $\mathrm{MeHg}$ induced apoptosis in ASK. However, in the same study, EPA had an opposing effect and decreased the uptake of $\mathrm{MeHg}$. Since we used a combination of these FA in our study, this could also mean that we had mixed increasing and decreasing effects on the uptake of $\mathrm{Cd}^{2+}$. However, this hypothesis needs further evaluation.

Another interessting result from our study was that the combined incubation of the FA and $\mathrm{Cd}^{2+}$ at the

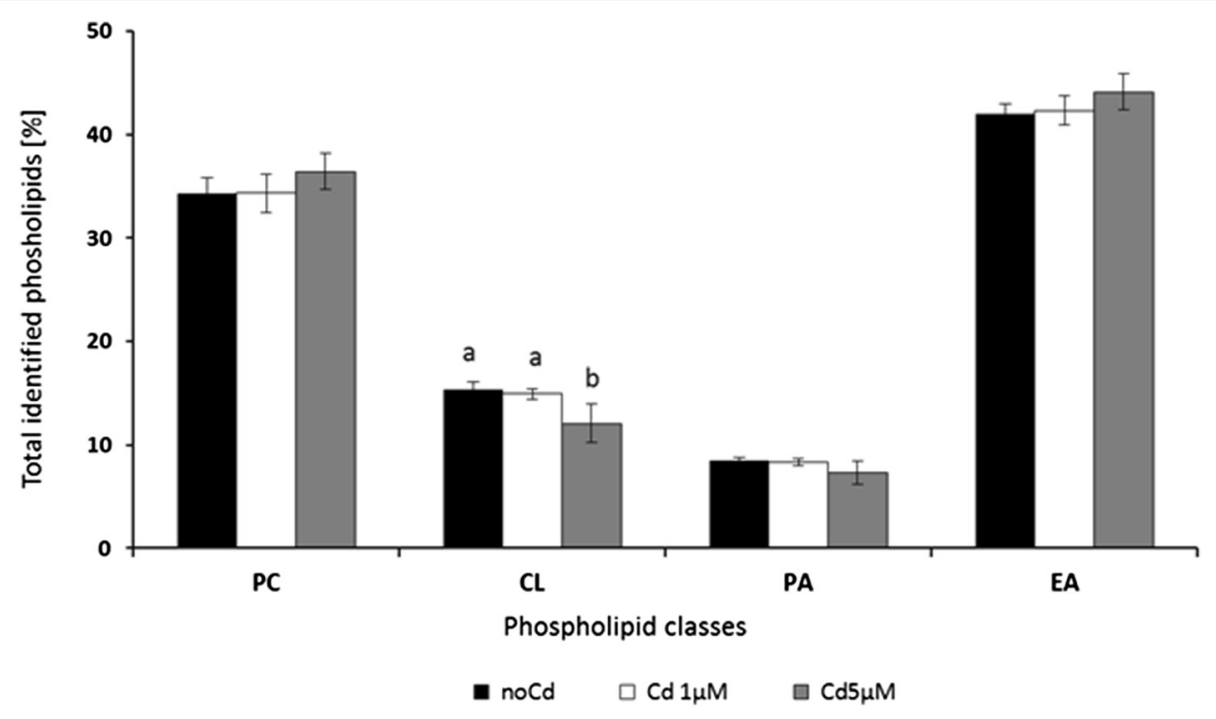

Fig. 5 Phospholipid class composition presented as percentage of total identified (means $\pm S D, n=3$ ) after in vitro pre-incubations of Hep G2 for $24 \mathrm{~h}$ with $5 \mu \mathrm{M}$ EPA+ $10 \mu \mathrm{M}$ DHA dissolved as BSA complex and $24 \mathrm{~h}$ post-incubations with/without $\mathrm{Cd}^{2+}$ at nominal concentrations of 1 and $5 \mu \mathrm{M}$ with changing culture (MEM) medium. Data are presented as means $\pm S D, n=3$. Different letters denote significant differences between treatments (two factorial ANOVA, $\left.\left(F A, \mathrm{Cd}^{2+}\right), p<0.05\right)$ 


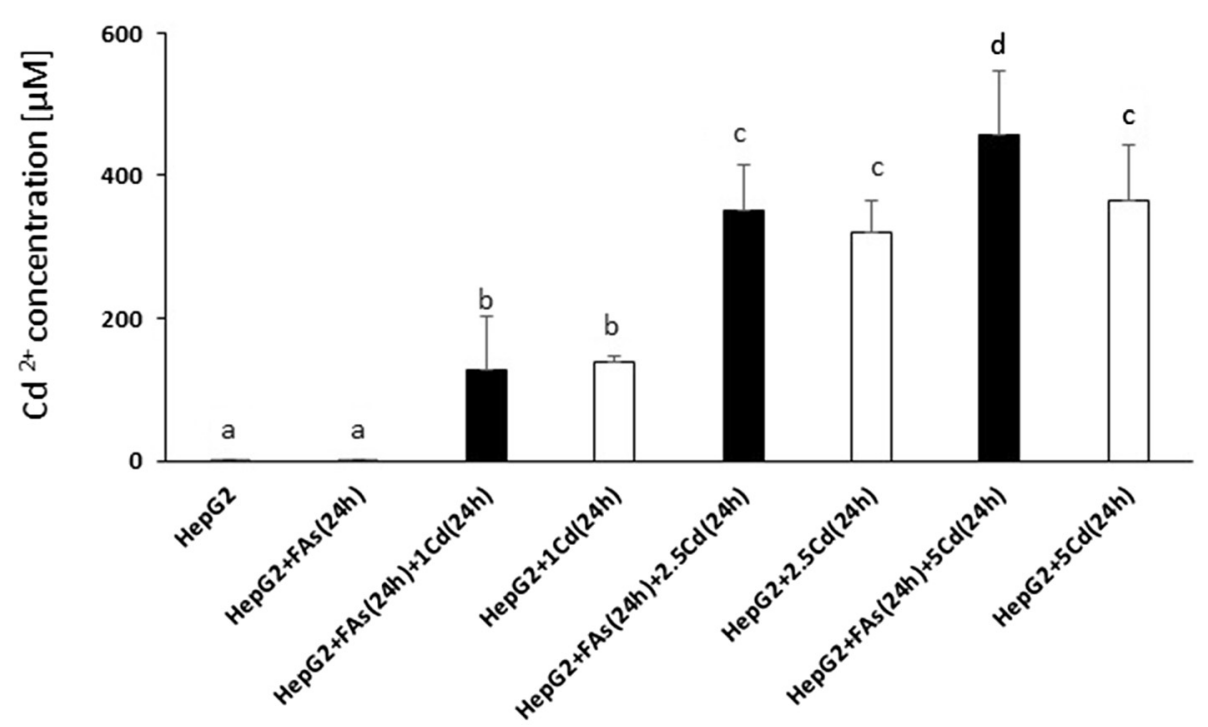

Fig. 6 Uptake of FA (24 h) and $\mathrm{Cd}^{2+}(1,2.5$ and $5 \mu \mathrm{M})$ for $24 \mathrm{~h}$ after in vitro incubations on Hep $\mathrm{G} 2$ cells with changing culture (MEM) medium. 'No FA' means cells were only incubated with BSA as control. Data are presented as means $\pm S D, n=3$. Different letters denote significant differences between treatments (two factorial ANOVA, $\left.\left(F A, C d^{2+}\right), p<0.05\right)$

highest level increased the proportion od DPA in the cells. This indicates either an upregulated metabolism from EPA towards the longer chain products or an increased $\beta$-oxidation from DHA due to energy needs of the cells or oxidative stress. We hypothecize that $\mathrm{Cd}^{2+}$ has an enhancing effect on these processes. Therefore, the next step should be to evaluate various levels of oxidation and antioxidant response on the cells as well as the protein expression of the related elongases.

\section{Conclusion}

The findings of the present study showed that the applied FA were taken up by the cells and that subsequent incubation with $\mathrm{Cd}^{2+}$ did not decrease the contents of EPA and DHA. However, as a possible adverse effect, the combined incubation of FA and $\mathrm{Cd}^{2+}$ resulted in a significantly increased uptake of $\mathrm{Cd}^{2+}$ at the highest used levels. The possible toxic effects of this findings in vivo should be evaluated.

It should be highlighted that both FA (EPA and DHA) reduced the detrimental effect of $\mathrm{Cd}^{2+}$ on cell viability, which is the most relevant finding of present study with potentially important implications regarding fish consumption.

Further, the combined incubation of EPA and DHA and $\mathrm{Cd}^{2+}$ increased the levels of DPA in the total lipid content of the cells, which could either be a sign of increased metabolism from EPA to DPA or increased $B$-oxidation from DHA to DPA induced by the cadmium. We also found that incubation with $\mathrm{Cd}^{2+}$ decreased $\mathrm{CL}$, an essential phospholipid class in the mitochondria, indicating that part of the toxic effects of cadmium is related to mitochondria dysfunction. However, the reason for the increased DPA values needs to be investigated as well as the general oxidative stress parameters, which will be the subject of our further work.

\section{Abbreviations}

AA: arachidonic acid (C20:4 n-6); BSA: bovine serum albumin; BSA-FA: bovine serum albumin complex with fatty acids; $\mathrm{Cd}^{2+}$ : cadmium chloride; $\mathrm{CL}$ : cardiolipin; DHA: docosahexaenioc acid (C22:6 n-3); DPA: docosapentaenoic acid (C22:5 n-3); EA: phosphatidylethanolamine; EPA: eicosapentaenoic acid (C20:5 n-3); FA: fatty acids; MEM: Minimum Essential Medium Eagle; PA: L-aphosphatidic acid; PBS: phosphate saline buffer; PC: L a-phosphatidylcholine: PUFA: polyunsaturated fatty acids.

\section{Competing interests}

The authors declare that they have no competing interests.

\section{Authors' contributions}

PL executed the cell culture work and the analyses related to cell viability and cadmium uptake and wrote major parts of the manuscript. Statistical evaluation was done together by both authors. SS was responsible for the study design, executed all lipid and fatty acid related analyses and wrote parts of the manuscript. All authors read and approved the final manuscript.

\section{Acknowledgments}

The study was financially supported by the Ministry of Education, Youth and Sports of the Czech Republic - projects "CENAKVA"[No.CZ.1.05/2.1.00/ 01.0024] and "CENAKVA II"[No. LO1205 under the NPU I program], by the Grant Agency of Czech Republic [GACR No. 13-01543S] and by the Grant Agency of the University of South Bohemia in Ceske Budejovice [GAJU No. 134/2013/Z]

The authors wish to thank Prof. William L. Shelton, Ph.D. for his valuable help with English correction and scientific edition.

Received: 30 July 2015 Accepted: 25 November 2015

Published online: 01 December 2015 


\section{References}

1. Sioen I, De Henauw S, Van Camp J, Volatier JL, Leblanc JC. Comparison of the nutritional-toxicological conflict related to seafood consumption in different regions worldwide. Regul Toxicol Pharm. 2009;55(2):219-28.

2. Sioen I, Matthys C, De Backer G, Van Camp J, Henauw SD. Importance of seafood as nutrient source in the diet of Belgian adolescents. J Hum Nutr Diet. 2007;20(6):580-9.

3. Sioen I, De Henauw S, Verdonck F, Van Thuyne N, Van Camp J. Development of a nutrient database and distributions for use in a probabilistic risk-benefit analysis of human seafood consumption. J Food Compos Anal. 2007;20(8): 662-70.

4. Lund EK. Health benefits of seafood; Is it just the fatty acids? Food Chem. 2013;140(3):413-20

5. Rudkowska I, Marcotte B, Pilon G, Lavigne C, Marette A, Vohl MC. Fish nutrients decrease expression levels of tumor necrosis factor-alpha in cultured human macrophages. Physiol Genomics. 2010;40(3):189-94.

6. Dorea JG. Fish meal in animal feed and human exposure to persistent bioaccumulative and toxic substances. J Food Protect. 2006;69:2777-85.

7. Chamannejadian A, Gholamabbas S, Abdolamir M, Alireza J. Evaluation of estimated daily intake (EDI) of cadmium and lead for rice (Oryza sativa L.) in calcareous soils. Iran J of Environ Healt. 2013;10:28-32.

8. Mates JM, Segura JA, Alonso JA, Marquez L. Roles of dioxins and heavy metals in cancer and neurological diseases using ROS-mediated mechanisms. Free Rad Biol Med. 2010;49(9):1328-41.

9. IARC, International Agency for Rearch on Cancer. Meeting of the IARC working group on beryllium, cadmium, mercury and exposures in glass manufacturing industry. Scand J Work Environ Health. 1993;19:360-3.

10. WHO. Guidelines for Drinking Water Quality, Second edition. WHO: Geneva; 1997.

11. Jarup $L$. Health effects of cadmium exposure a review of the literature and a risk estimate. Scan J Work Env Health. 1998;24:11-51.

12. Tirkey A, Shrivastava P, Saxena A. Bioaccumulation of Heavy Metals in Different Components of two Lakes Ecosystem. Curr World Environ. 2012; 7(2):293-7.

13. Innis SM. Essential fatty acids in growth and development. Prog Lipid Res. 1991;30(1):39-103

14. Gerster H. Can adults adequately convert alpha-linolenic acid (18: 3n-3) to eicosapentaenoic acid (20:5n-3) and docosahexaenoic acid (22:6n-3)? Int J Vitam Nutr Res. 1998:68(3):159-73.

15. Arts MT, Ackman RG, Holub BJ. "Essential fatty acids" in aquatic ecosystems: a crucial link between diet and human health and evolution. Can J Fish Aquat Sci. 2001;58(1):122-37.

16. Burdge GC, Jones AE, Wootton SA. Eicosapentaenoic and docosapentaenoic acids are the principal products of linolenic acid metabolism in young men. Brit J Nutr. 2002;88(4):355-64.

17. Valko M, Leibfritz D, Moncol J, Cronin MT, Mazur M, Telser J. Free radicals and antioxidants in normal physiological functions and human disease. Int J Biochem Cell B. 2007:39:44-84.

18. $\mathrm{FAO}, \mathrm{WHO}$. Report of the joint FAO/WHO expert consultation on the risks and benefits of fish consumption. In: FAO Fisheries and Aquaculture report vol. 978. Rome, Italy, 2010. http://www.fao.org/docrep/014/ba0136e/ ba0136e00.pdf. Accessed 25 Jan 2010

19. Gochfeld M, Burger J. Good Fish/Bad Fish: A Composite Benefit-Risk by Dose Curve. Neuro Toxicol. 2005;26(4):511-20.

20. Mahaffey KR, Sunderland EM, Chan HM, Choi AL, Grandjean P, Marien K, et al. Balancing the benefits of $n-3$ polyunsaturated fatty acids and the risks of methylmercury exposure from fish consumption. Nutr Rev. 2001;69(9): 493-508.

21. IARC. Beryllium, Cadmium, Mercury, and Exposures in the Glass Manufacturing Industry. IARC Monogr Eval Carc. 1997;58

22. Repetto G, del Peso A, Zurita JL. Neutral red uptake assay for the estimation of cellviability/cytotoxicity. Nat Protoc. 2008;3(7):1125-31.

23. Bueno C, Villegas ML, Bertolotti SG, Previtali CM, Neumann MG, Encinas MV. The excited-state interaction of resazurin and resorufin with amines in aqueous solutions. Photophysics and photochemical reactions. Photochem Photobiol. 2002;76(4):385-90.

24. Hara A, Radin NS. Lipid extraction of tissues with low toxicity solvent. Anal Biochem. 1978;90:420-6.

25. Moreau RA. The analysis of lipids via HPLC with a charged aerosol detector. Lipids. 2006;41(7):727-34

26. Appelqvist LA, Stumpf PK, von Wettstein D. Lipid synthesis and ultrastructure of isolated barley chloroplasts. Plant Physiol. 1968;43(2):163-87.
27. Sampels S. Fatty Acids and antioxidants in reindeer and red deer - emphasis on animal nutrition and consequent meat quality. Swedish University of Agriculture, Uppsala: Sweden. 2005;25(2):85-96.

28. Meyer S, Matissek M, Muller SM, Taleshi MS, Ebert F, Francesconi KA, et al. In vitro toxicological characterisation of three arsenic-containing hydrocarbons. Metallomics. 2014;6(5):1023-33.

29. Domingo JL. Omega-3 fatty acids and the benefits of fish consumption: Is all that glitters gold? Environ Int. 2007;33:993-7.

30. Di Nunzio M, Valli V, Bordoni A. Pro- and anti-oxidant effects of polyunsaturated fatty acid supplementation in HepG2 cells. Prostag Leukotr ESS. 2011;85(3-4):121-7.

31. Lindskog M, Gleissman H, Ponthan F, Castro J, Kogner P, Johnsen Jl. Neuroblastoma cell death in response to docosahexaenoic acid: sensitization to chemotherapy and arsenic-induced oxidative stress. Int J Cancer. 2006;118: 2584-93.

32. Jaudszus A, Gruen M, Watzl B, Ness C, Roth A, Lochner A, et al. Evaluation of suppressive and pro-resolving effects of EPA and DHA in human primary monocytes and T-helper cells. J Lipid Res. 2013;54(4):923-35.

33. Falconer JS, Ross JA, Fearon KC, Hawkins RA, O'Riordain MG, Carter DC. Effect of eicosapentaenoic acid and other fatty acids on the growth in vitro of human pancreatic cancer cell lines. Br J Cancer. 1994;69(5):826-32.

34. Merendino N, Costantini L, Manzi L, Molinari R, D'Eliseo D, Velotti F. Dietary omega -3 polyunsaturated fatty acid DHA: a potential adjuvant in the treatment of cancer. Biomed Res Int. 2013;23(10):310186. doi:10.1155/310_2013 186.

35. Obermeier H, Sellmayer A, Danesch U, Aepfelbacher M. Cooperative effects of interferon-gamma on the induction of NADPH oxidase by retinoic acid or 1.25(OH)2-vitamin D3 in monocytic U937 cells. Biochim Biophys Acta. 1995:1269(1):25-31.

36. Fujiyamafujiwara Y, Umeda R, Igarashi O. Metabolism of arachidonic, eicosapentaenoic, and docosahexaenoic acids in Hep G2 cells and rat hepathocytes. J Nutr Sci Vitaminol. 1992;38(4):329-34.

37. Paradies G, Petrosillo G, Paradies $V$, Ruggiero FM. Role of cardiolipin peroxidation and $\mathrm{Ca}^{2+}$ in mitochondrial dysfunction and disease. Cell Calcium. 2009;45(6):643-50

38. Nostbakken OJ, Bredal IL, Olsvik,PA, Huang TS, Torstensen BE. Effect of Marine Omega3 Fatty Acids on Methylmercury-Induced Toxicity in Fish and Mammalian Cells In Vitro. J Biomed Biotechnol. 2012; doi: 10.1155/2012/417652.

\section{Submit your next manuscript to BioMed Central and we will help you at every step:}

- We accept pre-submission inquiries

- Our selector tool helps you to find the most relevant journal

- We provide round the clock customer support

- Convenient online submission

- Thorough peer review

- Inclusion in PubMed and all major indexing services

- Maximum visibility for your research

Submit your manuscript at www biomedcentral com/submit 